\title{
Easy Rider og drømmen om frihed
}

\section{En motorcykelmyte}

I løbet af de forgangne 40 år har motorcyklen udviklet sig fra sig et transportmiddel til et livsstilsprodukt. Netop den proces ville ikke have kunnet gennemføres, hvis ikke en lang række andre begivenheder i tresserne havde fundet sted. Årtiet fra 1960-70 og det ungdomsoprør, som var kendetegnende for det, har været normdannende for en meget stor del af den kulturelle virkelighed, som vi befinder os i i dag. Det gælder ikke kun den nuværende pop- og rockkultur, som ville have været utænkelig uden The Beatles, Rolling Stones, Bob Dylan og mange flere. Også de øvrige kunstarter, vores politiske idealer, seksualnormer og vores forestillinger om det gode liv ville have været radikalt anderledes, hvis tresserne blot havde været en historisk parentes.

Den myte, som jeg vil kigge nærmere på i dette essay, hvis symbolværdi rækker langt udover selve motorcykelkulturen, skabte et begreb som Live to Ride, Ride to Live. Myten blev grundlagt af en film, lanceret i 1969, som var Oscarnomineret, men som aldrig fik sin ellers velfortjente statuette. Det drejer sig om den legendariske roadmovie Easy Rider med Peter Fonda, Dennis Hopper og en ung Jack Nicholson i hovedrollerne. Filmen fik stor gennemslagskraft, og mytens betydning for flere generationer af motorcyklister og for motorcykelkulturen i det hele taget er ikke til at komme udenom.

Man kunne hævde, at denne myte kun har med motorcykler at gøre, og choppere i særdeleshed, men jeg mener, at den kom til at påvirke hele Vestens syn på forholdet mellem mainstreamkultur og modkulturer, og ikke bare motorcykelkulturen. Det hænger sammen med, at tresserne påvirkede samfundet $\mathrm{i}$ en retning, der gjorde det muligt, at man pludselig begyndte at interessere sig for fænomenet livsstil og ikke mindst begyndte at genoverveje spørgsmålet om personlig frihed.

Ganske vist kørte mytens helte rundt på det, man vil kalde for vaskexgte California choppere, ${ }^{1}$ hvilket kan formidle det indtryk, at det var det, sagen drejede sig om. Men det beror på en ren tilfældighed, som mytens skaber, Peter Fonda, da også har indrømmet i sine kommentarer til den: 
"Nobody would ever ride so far on such kind af bikes", hvorved han mere end antydede, at ingen ved deres fulde fem nogensinde ville kunne finde på at køre en tur på over $3.000 \mathrm{~km}$ på California choppere. ${ }^{2}$ En af Harley-Davidsons store touringmodeller ville have været et langt mere troværdigt alternativ, men den tilbagelænede chopper-stil passede nu en gang bedre til mytens form.

Jeg vil i dette essay - på baggrund af mine personlige erfaringer som motorcyklist - forsøge at komme med et bud på en tolkning af Easy Rider og mytens betydning for den opfattelse af frihed, som deles af mange med en erklæret glæde ved et liv på to hjul. Afslutningsvis vil jeg argumentere for, at den frihedsopfattelse, filmen omhandler, peger i retning af nogle almenmenneskelige livsvilkår, og derfor ikke udelukkende bør tolkes politisk, sådan som den - især i en amerikansk kontekst - ofte er blevet det.

\section{Easy Rider}

Easy Rider hører til den genre, man kalder roadmovie, hvilket betyder, at en stor del af handlingen udspiller sig som hovedpersonernes rejse fra A til B. For denne films vedkommende drejer det sig om en rejse på motorcykler. Det antydes allerede i titlen, Easy Rider, hvad det handler om: Heltenes, Wyatt (Peter Fonda), Billy (Dennis Hopper) og George Hanson (spillet af Jack Nicholson, der i øvrigt via denne film fik sit internationale gennembrud) motorcykeltur fra Los Angeles i Californien til Mardi Gras festivalen i New Orleans i staten Louisiana. Distancen er den samme som fra Oslo i Norge til Palermo på Sicilien. Men titlen er dobbelttydig. Det, der i begyndelsen ser ud som en skøn tur i pragtfulde naturomgivelser med fed underlægningsmusik, udvikler sig til et tragisk møde med den barske virkelighed, der ikke levner plads til de tre frihedssøgende sjæle.

Easy Rider var Peter Fondas idé, og det stod fra begyndelsen klart for ham, at Dennis Hopper skulle være hans medspiller og filmens instruktør. Fondas ambition med filmen var at præsentere et tidsbillede af tressernes USA, inden æraen var forbi. Filmen skulle ifølge Fonda handle om motorcykler, sex og marihuana (Fonda 1998: 242). At den endte med at dreje sig om meget mere end det, er en helt anden historie, som jeg vender tilbage til.

Epoken var præget af rockmusik, hippier, frigjorthed og livsglæde, men også af småborgerligt snæversyn, Vietnam-krigen, racehad, demonstrationer og politiske uroligheder. Tressernes USA var en tumultarisk 
tid, hvor Borgerrettighedsbevægelserne og ungdomskulturen udfordrede mainstreamkulturens opfattelse af den amerikanske nation og identitet. Fonda ville fastholde dét indtryk. Udgangspunktet var, at de begge skulle medfinansiere filmen. Det var nemlig betingelsen for, at de kunne få andre og risikovillige investorer med på vognen. Det betød, at Hopper og Fonda, der i øvrigt begge var fuldstændig uden erfaring som instruktør og producer, blev tvunget til også at sætte deres egne og forholdsvis beskedne formuer på spil. Filmen havde, set med Hollywood-briller, et minimalistisk budget på blot $\$ 375.000$ (Klinger 1997: 179). Der skulle spares på alle leder og kanter. For eksempel lagde en af skuespillerne, den berømte Phil Spector, sin egen bil til - en Rolls Royce. Det tvang producenterne til at udvise en kreativitet, der rakte ud over, hvad der var almindeligt indenfor branchen. Det hører selvfølgelig med til myten, at denne B-films produktion endte med at indspille for over \$60 millioner (Lev 2001: 5). Det beskedne budget tvang filmskaberne til at optage en del af filmen med håndholdt $16 \mathrm{~mm}$. kamera mod normalt $32 \mathrm{~mm}$. Mange af optagelserne minder dermed om det, der årtier senere herhjemme blev kendt som dogmekonceptet. Det er hævet over enhver tvivl, at filmen, udover selve indholdet og budskabet, også med dens optage- og klippeteknikker kom til at danne skole inden for filmproduktionen.

Bortset fra de tre nævnte (Hopper, Fonda, Nicholson) samt Karen Black, Luke Askew og Toni Basil, blev filmen indspillet uden egentlige skuespillere, men derimod med amatører på lokaliteterne og helt uden stunts. Selv Peter Fondas egen fireårige datter, Bridget Fonda, medvirkede i en Hippie-lejr scene. Der var heller ikke noget egentligt filmmanuskript. Det eneste, der tjente som rettesnor for optagelserne, var et 21 sider langt dokument, som i stikord beskrev de enkelte scener. ${ }^{3}$ Peter Fonda beretter, at han havde lavet udkastet til filmens handling $i$ en sen nattetime efter at have konsumeret et par øl og en hel del joints. Replikkerne var noget, man fandt på undervejs. Det illustreres også af, at Dennis Hopper, Peter Fonda og ikke mindst Jack Nicholson virkeligt var skæve i en scene, hvor de tre i en sen aftentime under åben himmel i lejrbålets skær sidder og diskuterer væsener fra det ydre rum. Også på det punkt var filmen ret enestående.

\section{Rejsen mod frihed}

Filmen indledes med en scene, hvor Wyatt og Billy kører fra det sydlige Californien til Mexico på to små to-takts motorcykler. De ankommer til 
en lille landsby, hvor de tilsyneladende på forhånd har aftalt at indkøbe en større mængde narkotika, som de så efterfølgende skal smugle til Los Angeles. Eftersom stoffet afprøves via indsnusning gennem næsen, tyder alt på, at der er tale om kokain (i virkeligheden var det puddersukker). Det stemmer også med Peter Fondas eget udsagn: Han ville bruge noget, som var stærkere end almindelig marihuana, men ville dog ikke skabe associationer til heroin. Det er derfor heller ikke tilfældigt, at The Pusher med Steppenwolf spilles som underlægningsmusik til netop den scene. Stoffet videresælges i næste scene med stor fortjeneste til en rig forretningsmand (spillet af Phil Spector) i udkanten af Los Angeles lufthavn. Herefter skifter billedet til et sted i det sydøstlige Californien i et ørkenområde nær ved Colorado River, på grænsen til staten Arizona. Wyatt og Billy bruger noget af deres fortjeneste til at købe de berømte motorcykler, Captain America og Flame and Fire. De resterende penge skjules i et plastikrør, som gemmes i tanken på Captain America. Som en slags symbolsk handling, løsner Wyatt sit armbåndsur og smider det i ørkensandet. Tiden spiller ikke længere nogen rolle. Ude i det åbne landskab er der ingen ure, ingen grænser - kun de to bikere på deres maskiner. Underlægningsmusikken skifter til Steppenwolfs Born to be wild:

Get your motor runnin', head out on the highway

Wyatt og Billy kører mod øst. De kører hele dagen. Fra nu af skifter filmens fokus til de forskellige mennesketyper, heltene møder. En af dem, de møder undervejs, er en blaffer (Luke Askew), som får lov til at komme bag på Captain America. Blafferen er på vej til sit hippie-kollektiv, som befinder sig i et uvejsomt område i Arizonas naturskønne bjerge. Han inviterer Wyatt og Billy til at følge med sig hjem. Ved ankomsten til kollektivet går det op for de to helte, at beboerne er så fattige, at de knap nok har råd til at få mad på bordet. Kollektivisterne sulter. Ganske vist forsøger de at så afgrøder. Men de har ikke selv megen tiltro til projektet, fordi jorden er udtørret og gold. For at understrege det groteske i situationen, har de oven i købet besøg af nogle mennesker fra et andet kollektiv, som har specialiseret sig $\mathrm{i}$ at spille uforståelige teaterforestillinger. Opholdet fortsætter med en badescene med nogle piger i en nærliggende sø fra kollektivet. Herefter lykkedes det Billy at overtale Wyatt til at fortsætte rejsen.

Lidt senere er Wyatt og Billy på landevejen igen. De ankommer til en lille by, formentlig i Texas, hvor der er ved at blive afholdt en velgøren- 
hedsparade. Billy og Wyatt kommer ufrivilligt til at danne en lidt komisk bagtrop til optoget, hvilket får den lokale sherif til at arrestere dem for ulovlig deltagelse. De bliver smidt i det lokale fængsel. Politifolkene har tilsyneladende ikke meget til overs for to langhårede originaler på frække motorcykler. I spjældet møder de en mand, som har ligget og sovet en brandert ud. Det viser sig at være den lokale advokat, George Hanson (Jack Nicholson), som var blevet sat i detentionen på grund af druk. På trods af sit alkoholproblem nyder George Hanson tilsyneladende vis respekt hos betjentene, og det lykkes ham derfor at overtale vicesheriffen til at løslade dem alle tre, hvorefter de bliver enige om at følges ad. George sætter sig bag på Wyatt. Rejsen fortsætter og kørestilen er afslappet, frigjort og yderst tilbagelænet.

Efter solnedgang ender dagsrejsen med et lejrbål ude i de fri. Selv om George i begyndelsen er afvisende på grund af sin alkoholafhængighed, lykkes det Wyatt at overtale ham til at ryge en joint. Billy, som har røget et stykke tid, opdager pludseligt et flyvende objekt på himlen. George forklarer ham at der er tale om et UFO, som kommer fra et andet solsystem, og at regeringen, har haft kendskab til dem længe. Han forklarer yderligere, at de kommer fra et meget mere veludviklet samfundssystem uden krig, pengevæsen og lederskab, og hvor hver borger er sin egen leder. Årsagen til den lykkelige tilstand er, at de på grund af deres teknologiske udvikling, som er meget længere fremme end vores, har udviklet et idealsamfund, som vi kun kan drømme om.

Billy er skeptisk overfor Georges syrede konspirationsteori. Han affærdiger Georges snak som en vanvittig ide og spørger hvorfor regeringen så ikke har afsløret dem. Det gør regeringen netop ikke, hævder George, fordi det i så fald ville udløse en verdensomspændende panik. Der er stadig ledere. Og de forhindrer, at oplysningerne om UFOerne kommer frem, fordi det vil medføre et totalt sammenbrud af vores forældede samfundssystem. Herefter klippes til næste scene ved daggry, hvor de tre helte på stribe står og lader vandet ude ved vejkanten.

Dagens rejse slutter med, at de tre når frem til den vestlige del af Louisiana. En del af husene i velhaverkvartererne er smykket med nationalsymbolet over dem alle, Stars and Stripes. Velhaverkvarteret afløses senere af et meget fattigt distrikt, hvorved Sydstaternes voldsomme sociale kontraster bliver synlige. Her beslutter vennerne sig for at gøre ophold i en lille cafe for at spise aftensmad. Heltene har nu for alvor lagt de åbne landskaber i sydveststaterne bag sig, hjemstedet for de oprindelige indbyggere 
og nybyggernes realisering af den amerikanske drøm, som er blevet afløst af Sydens provinsielle forstadskultur. Selve betydningen af dette skift i filmens geografiske lokaliteter vender jeg tilbage til.

Inde på caféen sidder der en gruppe rednecks sammen med den lokale sherif og nogle gymnasiepiger. Sheriffen ophidser de øvrige ved at betegne heltene som troublemakers. Bortset fra de fnisende gymnasiepiger, som viser interesse for heltene, udviser sheriffen og alle de andre gæster efterhånden en så negativ holdning, at motorcyklisterne vælger at forlade stedet med uforrettet sag. Det er tydeligt, at Wyatt, Billy og George udgør en trussel mod byens patriarkalske orden, og at de er uønskede.

Vennerne ender igen ude i de fri. Her forsøger de at finde en forklaring dagens negative oplevelse. George indleder filmens centrale lejrbålsscene med en replik, der er gået over i filmhistorien som en af tressernes mest berømte oneliners:

You know, this used to be a hell of a good country. I can't understand what's gone wrong with it.

"De er bange for os," hævder Billy. ${ }^{4}$ George er ikke enig, og det bliver ham, der formulerer den skarpeste analyse af situationen. Han hævder, at indbyggerne ikke frygter Billy og Wyatt som personer, men derimod for det, de står for. Billy og Wyatt inkarnerer frihed, forklarer George. "Hvad er der galt med friheden", spørger Billy, "det er jo den, alle taler om?". "Det er korrekt", svarer George. "Men at tale om frihed er noget helt andet end at være fri", tilføjer han og fortsætter:

Det er meget svært at være fri, når alting handler om penge og når man er købt og solgt på et marked. Lad endelig være med at fortælle nogen, at de ikke er frie, for så ryger de lige i flæsket på dig for netop at bevise, at de er det. De vil holde lange foredrag for jer om den personlige frihed, men når de endelig får øje på et frit individ, bliver de virkelig bange, og det gør dem farlige.

Alle i Amerika taler om frihed men er bange for den ægte vare. Georges replik sætter altså spørgsmålstegn ved selve den amerikanske mainstreamkulturs opfattelse af frihed, som han stiller op overfor et oprindeligt frihedsbegreb med rod i den amerikanske selvforståelse af The Land of the Free. Det er denne frihedsopfattelse, Billy og Wyatt ifølge George inkarnerer, men som er blevet undertrykt og gjort til en kommerciel størrelse.

Mens de sover, bliver de overfaldet af de samme rednecks fra caféen. Alle tre bliver de gennembanket med macheter og baseballkøller $\mathrm{i}$ et sandt 
orgie af vold og raseri. Værst går det ud over George. Han bliver slået ihjel. Wyatt og Billy er lamslåede og aner ikke, hvad de skal stille op med liget og Georges ejendele. Heriblandt finder de lidt penge, hans kørekort og et visitkort til et bordel i New Orleans. Herefter fortsætter rejsen til New Orleans og det bordel, House of Blue Lights, som stod på Georges visitkort, hvor de møder de to prostituerede, Karen (Karen Black) og Mary (Toni Basil). Sammen deltager de alle fire i Mardi Gras festlighederne i New Orleans' gader. De ender til sidst på en kirkegård i udkanten af byen, hvor de indtager et stærkt stof (sandsynligvis LSD) og dyrker sex sammen med pigerne. Næste dag fortsætter turen, videre mod øst. Wyatt og Billy sidder igen på motorcyklerne. De har besluttet sig for at drage videre til Florida.

Efter dagens rejse møder vi dem igen ude i det fri i filmens sidste lejrbålsscene. Stemningen er ikke den samme som før. Heltene forsøger at opmuntre og trøste hinanden, men virker underligt desillusionerede. Alligevel siger Billy: "We've done it. We're rich, Wyatt." Wyatts svar "You know, Billy, we blew it" er filmens mest gådefulde replik, idet det ikke står klart, hvad Wyatt henviser til. Muligvis henviser han til Georges død eller til, at deres rejse mod frihed blev finansieret ved hjælp af en ulovlig narkohandel. Eller at deres søgen efter et andet Amerika endte blindt. Den sidste tolkning ville svare til filmplakatens udsagn: "A man went looking for America. And couldn't find it anywhere..."

Næste morgen er de på landevejen igen. Her bliver de overhalet af en pickup-truck, hvori der sidder to rednecks. Passageren i bilen rækker ud efter et haglgevær, som befinder i et stativ ved bagruden af bilen. Hensigten er at forskrække Billy, men skuddet rammer - måske ved et uheld - og Billy styrter. Det er ikke til at se om han bliver ramt eller om det er skuddets brag, der forskrækker ham så meget at han mister balancen.

Wyatt, som kører forrest, standser og vender om for at se efter sin ven. Wyatt opdager, at Billy er hårdt såret, men om det er skuddet eller styrtet, der har forårsaget det, står hen i det uvisse. Wyatt gør sig klar til at hente hjælp, men også de to rednecks er vendt om. Da Wyatt passerer dem, falder der endnu et skud. Nu er det motorcyklen, Captain America, der bliver ramt. Den eksploderer og Wyatt slynges af. Scenen afsluttes med et omvendt zoom optaget i fugleperspektiv fra en helikopter, hvor vi ser den brændende maskine. Rejsen mod frihed ender blindt. 


\section{Captain America \& Flame and Fire}

Også hvad angik de anvendte motorcykler var filmen ganske mageløs. De fortjener her en kort præsentation. Det drejede sig nemlig om to såkaldte California choppers, som, så sent som i 1969 var et forholdsvis ukendt fænomen blot halvtreds kilometer øst for Californiens statsgrænse. Eftersom filmen faktisk udviklede sig til en verdenssucces efter Oscar-nomineringen, blev den type motorcykler, altså kategorien chopper, for første gang eksponeret for et meget stort publikum.

Det interessante ved maskinerne var, at de ikke bare blev indkøbt til filmen, men at de blev specialfremstillet til den på et af de små værksteder i Californien. De blev konstrueret i to forskellige versioner og i tre eksemplarer af den legendariske sorte mekaniker Ben Hardy, som drev et lille motorcykelværksted i Los Angeles.

Eftersom Wyatt (Peter Fonda) var klædt i lædertøj, som skulle give associationer til tegneseriefiguren Captain America, blev hans motorcykel designet med et tilsvarende look, der fik modelbetegnelse efter figuren. Den blev fremstillet $i$ to eksemplarer, hvoraf den ene blev smadret under filmoptagelserne, og den anden efter sigende blev stjålet og aldrig genfundet. Senere er det smadrede eksemplar blev genopbygget og kan nu besigtiges på Barber Vintage Motorsports Museum, i Birmingham, Alabama.

Den motorcykel, som Billy (Dennis Hopper) kørte på, fik et lidt andet design, fordi han, i modsætning til Wyatt, der repræsenterede den amerikanske drøm, skulle visualisere de amerikanske pionerer. En cowboy. Han var klædt i ruskindsjakke med frynser på ærmerne og bar en bushman-hat. Motorcyklen fik navnet Flame and Fire på grund af flammemotiverne på tanken. Begge maskiner var modificeringer af Harley-Davidsons FLHF Hydra-Glide årgang 1957 med en såkaldt Panhead V-twin motor. Det særegne navn fik motoren, fordi topstykkerne lignede to omvendte kasseroller. Det bemærkelsesværdig i denne forbindelse var imidlertid, at motorcyklerne, på det tidspunkt da de blev ombygget til filmen, var over ti år gamle. Man kunne således på det tidspunkt (i 1968/69) have anvendt nogle af den berømte amerikanske motorcykelfabriks mere moderne alternativer.

Peter Fonda fortæller, at Hopper og han, efter en indspilningsdag var dødtrætte og fysisk udmattede, fordi de havde kørt så mange kilometer på motorcyklerne. Under optagelserne kørte de selv på chopperne, som mildest talt ikke var særlig komfortable på grund af manglende affjedring på 
baghjulet (deraf udtrykket hardtai). Man skal i den forbindelse huske på, at der blev optaget langt flere meter film, end der blev vist i den endelige biografversion.

Ben Hardy havde anvendt den oprindelige motor, gearkasse og stel. Resten var stort set hans eget værk. Captain Americas stel blev totalforkromet, mens det på Flame and Fire blev malet i en rød-orange kulør. Begge maskiner blev udstyret med en minimalistisk og dråbeformet benzintank (peanutshaped), som i det ene tilfælde blev overmalet med det amerikanske flag (Stars and Stripes) og i det andet, med flammemotivet. Kastervinklen på forgaflen på begge maskiner blev væsentligt forøget, lidt mere på Captain America. Styret på Captain America blev meget højt og buet, mens det blev lige og lidt lavere på Flame and Fire. Kørestillingen blev derfor særdeles tilbagelænet på Captain America, mens den blev lidt mere fremadrettet på Flame and Fire. En lille forlygte blev der også plads til, mens speedometer og forbremse (!) - dog kun på Captain America - blev kasseret. Den oprindelige store og affjedrede saddel blev erstattet af et mindre sæde, der blev placeret direkte på stellet. Det strakte sig fra tanken til enden af bagskærmen. Udstødningen blev ført bagud i to rør på højre side fra hver sin cylinder, opad i Fishtail stil på Captain America og vandret på Flame and Fire. Maskinerne var alt andet end komfortable at køre på.

Det fremgår hverken af Peter Fondas udtalelser eller af filmens handling, hvorfor netop de to motorcykler fra kategorien chopper kom til at spille en afgørende rolle i den. Peter Fonda sagde selv, at det udelukkende handlede om stil og ikke havde noget med sund fornuft at gøre: "It's all about style with no sense at all".

Skønt fænomenet (California-chopper) havde eksisteret i over tyve år, og selv om motorcyklerne via eksponeringen vakte en del forundring filmen viste for forste gang choppere for et meget stort publikum i en tid, hvor motorcyklen fortsat blev anvendt som et reelt transportalternativ til andre motoriserede køretøjer - ja så fik det ikke umiddelbart konsekvenser for produktionen af standardmotorcykler.

Potentialet - motorcyklen som et livsstilsprodukt - gik ikke op for motorcykelproducenterne allerede ved denne lejlighed, og slet ikke for Harley-Davidson. Der skulle gå endnu nogle år, inden tressernes krav om større tolerance, frigjorthed og søgen efter personlig frihed for alvor slog igennem i virksomhedernes produkt- og marketingstrategier (Peters og Peters 2011). 


\section{Billedet af tressernes modkultur}

Det, der i første omgang fik betydning var altså, at maskinerne skulle være synlige. De skulle være anderledes end det, man var vant til. Kun California-choppere kunne leve op til det idealbillede. De var den eneste mulighed, hvis man ville vække opmærksomhed - både i filmens eget indre handlingsunivers, men så sandelig også udenfor. Det samme gjaldt for de to hovedroller, Wyatt (Fonda) og Billy (Hopper), som med deres alternative udseende som en slags antihelte repræsenterede tressernes modkultur.

Men hvilke typer repræsenterede de? Modstandere af filmen, som samtidig har udtrykt sympati for det etablerede samfund, har ofte påstået, at der måtte være tale om kriminelle bandemedlemmer, og at de forskellige personers modstand overfor dem derfor ikke bare var forståelig, men ligefrem berettiget. Argumentet understøttes af det faktum, at Wyatt og Billy indledningsvis tjente penge ved narkosmugling. I hvor høj grad Easy Rider i de følgende årtier blev en skydeskive for konservative og reaktionære kræfter i USA understreges ret godt i en tale af George Bush (senior) fra 1988. Heri kunne han med stolthed meddele, at Amerika heldigvis var kommet sig ovenpå udskejelserne i det, han betegnede som "1960ernes easy rider-samfund". 5

Selv om det er korrekt, at heltene finansierer deres rejse mod frihed ved narkosalg, er der intet i Peter Fondas tilkendegivelser omkring filmen, hverken mundtlige eller skriftlige, der tyder på, at han havde kriminelle typer fra motorcykelbander i tankerne, da han skitserede plottet. Problemstillingen er noget mere kompleks.

Der er ingen tvivl om, at heltene på den ene side skulle repræsentere unge fra den alternative hippiescene, men næppe kriminelle bandemedlemmer. På den anden side kan der ikke herske nogen tvivl om, at der var tale om et par protagonister, der var i opposition til de etablerede normer og det hvide småborgerskab i datidens USA. Det understreges af deres provokerende udseende og handlemåde. Narkohandelen skal altså ikke nødvendigvis opfattes som om, det var deres profession, men snarere som en smart handling, der kunne skaffe dem penge på en nem og hurtig måde.

Heltene repræsenterer 'det andet Amerika', tressernes modkultur, hvor spontanitet, oprør og nydelse (seksuel og narkotisk) udgør forudsætningerne for den frisættelse, der udfordrer selve den amerikanske identitet og selvforståelse. Det er i den forbindelse at filmens lokaliteter kommer til at spille en central rolle, idet rejsen fra vest mod syd er en rejse gennem regi- 
oner og landskaber, der er ladet med politisk og national betydning (Klinger 1997). Første del af filmen foregår i Sydvestens storslåede og åbne landskaber, som understøttes af en tilsvarende åbenhed og gæstfrihed hos indbyggerne. I Sydstaternes forstadskvarterer hersker småborgerligt snæversyn, racisme og intolerance.

Filmen blev da også umådelig populær blandt den yngre generation af biografgængere og af mange kritikere hyldet som den første kommercielle film om sammenstødet mellem den nye ungdomskultur og den amerikanske mainstreamkultur (Miller 1969: 16, Glushanok 1969: 20-21). Den blev imidlertid også af mange i det amerikanske establishment opfattet som en voldsom provokation og af konservative meningsdannere og politikere udskældt som indbegrebet af USA's moralske forfald. Barbara Klingers analyse kan tolkes $\mathrm{i}$ den retning, at selve ordet Easy Rider især i Bush-Reagan-årene antog karakter af et ideologisk kampbegreb, som politiske grupper kunne bruge til at definere og ikke mindst dæmonisere de politiske modstandere med, på en måde, der udelukkede enhver dialog. (Klinger 1997). Filmens voldscener blev således videreført i den politiske kampretorik, der fik et ligeså ondartet udtryk, som den hetz heltene blev udsat for på deres rejse gennem Sydstaterne. Man kan derfor med god ret spørge, om denne film, der indskrev sig i en bestemt tid og en bestemt kulturkamp i tressernes USA, også har et budskab i dag.

\section{Hyldest til en æra?}

Som antydet i referatet, fik drømmen om frihed en dyster udgang. Givet er, at George døde, men om Wyatt og Billy fik den samme skæbne, lader filmen stå åbent. Det må publikum afgøre. Der er ingen tvivl om, at filmen var en hyldest til en særlig æra og et forsøg på at skildre en særlig tidsånd. Den afspejlede en hel generations håb og drømme om at bryde med samfundets fastlagte normer og søge nye veje og måder at indrette tilværelsen på. Lytter man til filmskaberens egne kommentarer, er denne fortolkning ret nærliggende.

Som sagt hævdede Peter Fonda, at han blot ville lave en film, som skulle handle om sex, marihuana og motorcykler som en afrunding af en æra (tresserne), inden det hele var forbi. Han ville skildre de modsætninger - også politiske, som æraen rummede som en slags hyldest til et ideal, der allerede var forsvundet, og som aldrig ville komme igen. Peter Fonda ville med filmen Easy Rider fastholde det billede og vise dets perspektiver, hvil- 
ket filmen med dens undertiden næsten dokumentariske optagelser, hvor de enkelte visuelle billeder taler for sig selv, understreger på smukkeste vis.

Det syn ligger meget tæt op ad Fondas egen biografi. Han var selv et typisk 68'er (født i 1940) og blev i tressernes Hollywood betragtet som dropout. Han havde tæt kontakt med de enkelte medlemmer af The Beatles, som han besøgte flere gange i deres hjem i Benedict Canyon, samtidig med at han også plejede omgang med mange andre fra tressernes rockscene, deriblandt The Byrds (David Crosby) og Buffalo Springfield (Stephen Stills). Han var samfundskritisk, venstreorienteret og deltog i flere demonstrationer, bl.a. i den navnkundige på Sunset Strip, som fik en voldelig og dødelig udgang efter politiet havde grebet ind.

På den baggrund lancerede rockgruppen Buffalo Springfield i øvrigt i 1967 sangen For What It's Worth med Stephen Stills som forsanger. Den blev i 2007 kåret som nummer 67 ud af 500 på listen over alle tiders mest berømte sange (Rolling Stone Magazine). Fonda forsøgte selv, uden held, at skabe sig en sangkarriere, bl.a. ved at indspille Donovans Catch The Wind.

Med Easy Rider vandt Fonda og Hopper stor respekt i Hollywood. Med beskedne midler og på en primitiv baggrund var det lykkedes dem at skabe et værk, som gik over i filmhistorien, og som blev en stor international publikumssucces og ikke mindst en økonomisk succes. I løbet af halvfjerdserne genoptog de deres Hollywood-karrierer og indspillede og instruerede en række film, hvoraf flere opnåede international anerkendelse og berømmelse. På en måde kan man sige, at det, der ikke lykkedes for heltene i filmen, lykkedes for Fonda og Hopper i det virkelige liv. De udfordrede skæbnen ved at lave en film om motorcykler, og de vandt.

Kort efter filmens premiere blev dens budskab fortolket ud fra modsatrettede politiske standpunkter. Fra venstreorienteret side er det samfundskritiske aspekt blevet fremhævet. Her spiller figuren George Hanson en afgørende rolle, som den samfundsrevser, der beskylder USA (og Vesten) for manglende frihedsrettigheder og overtrædelse af forfatningen. I filmen kommer det frem, at han er borgerrettighedsforkæmper og sympatiserer med organisationen American Civil Liberties Union (ACLU). Dette understreges af hans kritiske replik om, at det er så som så med friheden, når man har fornemmelsen af at være købt og solgt på et marked, frem for at blive respekteret som individ. Filmen blev opfattet som en anklage mod den kapitalistiske samfundsorden, småborgerligt hykleri og dobbeltmoral. Heltenes undergang betragtes som et bevis for, at Easy Rider netop skulle forstås på den måde. Den, der kritiserer den bestående orden, bliver nå- 
desløst slået ihjel. Forsøget på at skabe en ny livsform som et alternativ til den bestående orden er dømt til at mislykkes, fordi den bestående orden kvæler enhver modstand. Peter Lev peger således på, at filmens slutning kan opfattes som et allegorisk svar på samtidens uforsonlige politiske retorik, der konstant spillede på billeder af modstanderens udslettelse. Jonathan Aitken gengiver i sin Nixon-biografi republikaneren George Wallaces ofte citerede slogan fra valgkampen i 1968: "If one of them hippies lays down in front of mah car when Ah become President, that'll be the last car he lays down in front of." (Aitken 1993: 360) Dette citat illustrerer på glimrende vis den dæmoniserende kampretorik epoken bar præg af.

Filmen er altså blevet opfattet som en politisk provokation med udspring i ungdomsoprøret i 1968. Det vil sige en venstreorienteret samfundsomvæltning, der havde til formål at omstyrte eller forstyrre den bestående orden. Filmen idylliserede det kriminelle element (narkohandelen) og outsiderne, hævdedes det, og forsøgte at nedgøre lovlydige borgere og det arbejdende folk, selve den amerikanske middelklasse. Den havde, helt i tråd med den revolutionære ånd fra 68, ikke noget respekt for det parlamentariske demokrati, for lov, ret og orden. Dens budskab ansås dermed for at være direkte farligt. Filmen tegnede et rosenrødt billede af en urealistisk drøm, der i værste fald ville underminere samfundet - ergo var George Hansons og heltenes død i konservative kritikeres øjne intet andet end et retfærdigt offer.

Easy Rider rummer et stærkt samfundskritisk element. Selve roadmovie-genren bekræfter denne fortolkning, idet kløften mellem mainstreamkulturen og mod- eller subkulturer udstilles. Livet på vejen udgør et modbillede til det (små-)borgerlige livs statiske og magelige sathed. ${ }^{6}$ Filmens underlægningsmusik peger også i retning af dette. Her kan man blot tænke på Steppenwolfs budskab i Born to Be Wild og The Byrds' I Wasn't Born to Follow. Både Peter Fonda og Dennis Hoppers politiske sympatier lå dengang til venstre for midten og handlingen, indholdet og replikkerne i filmen bekræfter det. Men at konkludere, at filmen var rent politisk og uden andre budskaber, er en fejltolkning, der i værste fald kommer til at bekræfte kampretorikken, idet den monopoliserer modkulturens frihedsbegreb. En tolkning, der ikke reducerer filmen til dens politiske eller ideologiske budskab, men tager udgangspunkt i filmens skildring af almenmenneskelige livsvilkår, synes derfor langt mere frugtbar. 


\section{Den genvundne frihed}

Inden jeg afslutningsvist indlader mig på at skildre, hvad jeg opfatter som filmens kernebudskab, vil jeg lige - ganske kort - se på, hvad myten egentligt har med nutidens motorcyklister (indenfor alle kategorier og ikke kun choppere) og motorcykelkulturen som helhed at gøre.

Filmens helte, Wyatt og Billy, svinger sig op på deres motorcykler for at jagte og realisere deres drøm om personlig frihed, integritet og jeg-følelse. De drømmer om en god tur. Det er derfor, de begiver sig af sted. Spørger man de, der kører motorcykel anno 2011, er det præcis den samme jagt, der motiverer de fleste af os til at sætte os op på et køretøj, der i bund og grund er en reminiscens fra en svunden tid, da bilen var alt for dyr for den lavere middelklasse. Det tankevækkende i den forbindelse er, at handlingen i Easy Rider fik en ulykkelig udgang. Det sker heldigvis ikke for alle, der kører motorcykel, men det sker. Når det kan ske, må vi altså være villige til at betale prisen i form af lidelse og smerte, der $i$ alle henseender overtrumfer det, vi normalt oplever i hverdagen. Vil man være fri for smerte, må man være villig til at påtage sig en, der kan blive langt værre, synes filmens budskab til alle motorcyklister at være. Smerten frygter vi, fordi vi alle. De færreste af os rejser gennem livet med et konstant smil på læben. Lidelsen og smerten er en latent ledsager. Det gælder for os alle. Det ved vi, fordi det er et vilkår, vi alle deler med hinanden. Derfor har vi brug for trøst, som kan søges på mange måder. En af dem er, at sætte sig op på en motorcykel for at køre en tur. Når vi gør det, glemmer vi smerten og ærgrelserne for en stund og vender tilbage til livets vej med fornyede kræfter.

Når vi vælger at afsøge livets grænseegne ved hjælp af en motorcykel, på samme måde som heltene i Esay Rider, hænger det sammen med en kompliceret psykologisk mekanisme. En mekanisme, som netop knytter sig til motorcyklen og ikke til noget som helst andet. - Som forfatteren Ida Tin beskriver det i sin bog, Direktos: "Det er let at køre motorcykel, men det er overraskende svært at gøre det rigtig godt" (Tin 2009: 80). Derudover hævder hun, at der hele tiden er tale om en byttehandel med skæbnen, hvor det gælder om at afprøve sig selv og samtidig være villig til at betale prisen. På den ene side løber man en risiko og ofrer noget af sin sikkerhed, fordi man ved, at det farligere end som så - det kan gå grueligt galt - og på den anden side høster man det selvværd og den tilfredshed ved at køre, der giver fornyede kræfter til at kunne tåle livets genvordigheder.

Ida Tin skriver ud fra egne erfaringer. Hun er kvinde, i starten af 30erne (født 1979), eventyrer og motorcyklist. På den måde adskiller hun 
sig noget fra kvinder i almindelighed - men interessant nok ikke fra størstedelen af kvindelige motorcyklister, som har en gennemsnitsalder på 35 år. Uanset køn, kommer erkendelsen om livets smerte og lidelse for mange ofte forst i en moden alder. Når vi opdager det, tager vi, der er motorcyklister, en tur i det indre og ydre univers på vores motorcykler, som en afstikker fra livets roadmovie. Her opdager vi, "at der foregår så mange underlige ting derude. Folk opfinder, tænker og connecter", for at blive i Ida Tins sprogbrug (Tin 2009: XX). Vi gambler, sætter vores chip som indsats i rouletten og håber på at vinde.

\section{Livets roadmovie}

Betragter vi Easy Rider ud fra det perspektiv, er det præcis den samme søgen efter frihed, der gør sig gældende for heltene. De søger spændingen og det uvisse som en afstikker fra livets vej, hvorved de indgår en byttehandel med skæbnen. En byttehandel der er nødvendig for at finde frihed og fornyede kræfter. Men heltene tabte: "Billy, We blew it" som Wyatt profetisk påpeger overfor sin ven kort for den tragiske slutning. Heltene kom til at betale mere, end de fik til gengxld. Det er de ikke ene om. Ulykkesstatistikken for motorcyklister vidner om, at mange andre lider samme skæbne. Friheden på to hjul har en pris, som man må være villig til at betale. Men filmen vil mere end bare fortælle os, at det er farligt at køre på motorcykel, og at vi skal være bevidst om denne risiko. Man kan let fristes til at tro, at filmen udelukkende henvender sig til motorcyklister. Det gør den naturligvis ikke. Budskabet kan nemlig sagtens forstås som en metafor for noget almenmenneskeligt.

Livet er farligt og vi er ikke usårlige. Det kan hele tiden gå galt. Vi er konstant udsat for farer og skæbnens ugunst. Vi skal derfor påtage os et ansvar for livet og være os livets op- og nedture bevidst. Billedet af byttehandlen går igen her. Vores eksistens i sig selv udgør indsatsen, og vi er tvunget til at spille med. Vi kan ikke unddrage os. Men vi kan måske sikre os via ansvarlighed, troskab mod os selv, og de valg vi træffer, samt ved at hylde friheden. Det er rejsen, der er det springende punkt, både i filmen og $\mathrm{i}$ livets roadmovie. Den er vi fælles om. Vi befinder os alle, uden undtagelse, i livets roadmovie, hvor vi stræber efter frihed og anerkendelse. Og alle som én er vi tvunget til at se risikomomenterne i øjnene. Filmens helte var villige til at betale hele prisen. Det er man også som motorcyklist, hvis man har overvejet, hvorfor man gang på gang svinger sig op i sadlen. 


\section{Noter}

1 Motorcykelkategorien chopper er kendetegnet ved en lang forgaffel og stor akselafstand, fremflyttede fodhvilere og ekstrem lav sædehøjde plus masser af skinnende krom, lak og blankpoleret aluminium. Ordet chopper er afledt af det engelske ord chop, som på dansk betyder bakke eller bugge af. Kategorien opstod i Californien i kølvandet på Anden Verdenskrig, hvor en gruppe amerikanske krigsveteraner havde svært ved at leve sig ind i en rutinepræget og småborgelig hverdag. De søgte spænding ved at ombygge og reparere gamle udtjente militærmotorcykler, primært af mærket Harley-Davidsons model WLA, så de kunne komme til at køre hurtigere og bruges i væddeløb: "They chopped the bike", som det hed dengang i USA. I løbet af 50erne og 60erne opstod der overalt i Californien små værksteder, der mod passende betaling påtog sig opgaven med at modificere motorcykler. Begrebet California Chopper var dermed født.

2 Denne og de følgende gengivelser af Peter Fondas kommentarer til filmen, fremgår af bonusmaterialet til DVD-udgaven fra Columbia Pictures, der indeholder et langt interview, hvor Fonda beretter om filmens tilblivelse og ideerne bag.

3 Lee Hill peger dog på, at Hopper og Fonda samt manuskriptforfatter Terry Southern efter premieren bevidst nedtonede det intensive arbejdsforløb for at skabe myten om at filmen i det store og hele var improviseret. (Hill 1996: 19)

4 Dette og de følgende citater fra filmen er min oversættelse. Filmens berømte oneliners har jeg dog valgt at gengive i deres originale engelske form.

5 Citeret efter (Klinger 1997: 179).

6 Man kan her blot tænke på et af beat-kulturens mest berømte værker, Jack Kerouacs On the Road fra 1957, der kom til at danne skole for en hel generations kunstneriske fremstillinger af det frie liv.

\section{Litteratur:}

Aitken, Jonathan (1993): Nixon: A Life, Washington, D.C.: Regnery Publishing

Fonda, Peter (1998): Don't Tell Dad. A Memoir, New York: Hyperion.

Glushanok, Paul: 'Easy Rider', anmeldelse i Rat, juli 1969, s. 20-21.

Hill, Lee (1996): Easy Rider, London: British Film Institute Publishing.

Klinger, Barbara (1997): The Road to Dystopia. Landscaping the nation in Easy Rider in Cohan, Steven (red.): Road Movie Book, London: Routledge s. 179-204.

Lev, Peter (2000): American Films of the 70s. Conflicting Visions, Texas: University of Texas Press.

Miller, Francis Jr.: 'Easy Rider', anmeldelse i The Great Speckled Bird, september 1969, s. 16.

Peters, Lars Ove og Peters, Rikke Louise (2011): Fart, Stil og fribed. Motorcykelkulturen $i$ Danmark, Hadsten: Forlaget Motorploven.

Tin, Ida (2009): Direktos: et eventyr om at leve enkelt, lytte til sit hjerte og mode verden, København: Rosinante. 